\title{
Forensik Digital Kasus Penyebaran Pornografi pada Aplikasi Facebook Messenger Berbasis Android Menggunakan Kerangka Kerja National Institute of Justice
}

\author{
Syifa Riski Ardiningtias ${ }^{\# 1}$, Sunardi ${ }^{* 2}$, Herman $^{\# 3}$ \\ \#Magister Teknik informatika Universitas Ahmad Dahlan \\ Kampus 3 UAD Jl. Prof. Soepomo Yogyakarta \\ ${ }^{1}$ sraa.riski@gmail.com \\ 3hermankaha@mti.uad.ac.id \\ *Program Studi Teknik Elektro Universitas Ahmad Dahlan \\ Kampus 4 UAD Ring Road Selatan Yogyakarta \\ ${ }^{2}$ sunardi@mti.uad.ac.id
}

\begin{abstract}
Abstrak - Perbuatan kriminal pada jaman sekarang semakin berkembang salah satunya adalah kriminal kejahatan dengan memanfaatkan sosial media. Pertumbuhan pengguna smartphone berbasis Android untuk mengakses media dalam berkomunikasi menggunakan media sosial Facebook Messenger sangat cepat. aktivitas kejahatan sebagaimana penyebaran konten pornografi yang belakangan ini banyak digunakan dengan aplikasi Facebook Messenger. Penelitian ni dilakukan untuk mendapatkan bukti forensik kegiatan kejahatan penyebarluasan pornografi pada aplikasi sosial media Facebook Messenger yang diakses melalui aplikasi smartphone. Penyelidikan dalam penelitian ni menggunakan metode National nstitute of Justice (NIJ) yang menyediakan beberapa tahap dentification, preservation, collection, examination, analysis, dan presentation. Pengangkatan bukti digital perilaku kriminal menggunakan software perangkat lunak Magnet Axiom dan Belkasoft Evidence Center. Bukti digital dicari terhadap perangkat pelaku kriminal penyebarluasan pornografi yang disita dengan skenario kasus dengan 11 variabel sehingga didapatkan barang bukti berupa spesifikasi perangkat, akun Facebook Messenger, email, gambar, video dan audio. Hasil penelitian ni menunjukkan Magnet Axiom lebih baik dengan akurasi 90,91\% dibandingkan Belkasoft Evidence Center 46,66\%.
\end{abstract}

Kata kunci - Forensik Digital, NIJ, Facebook Messenger, Media Sosial, Penipuan

\section{Pendahuluan}

Manusia merupakan makhluk yang memilikin satu kebutuhan dasar yaitu berkomunikasi dan berinteraksi dengan sesame manusia. Semakin pesat perkembangan teknologi dan semakin maju merupakan kesatuan yang tidak dapat dilepas dari kehidupan manusia. Selain mempunyai sisi positif, perkembangan teknologi juga mempunyai sisi negatif berupa kasus kejahatan yang seiring pengguna aktif sosial media [1]

Setiap tahun kasus criminal di dunia maya selalu meningkat. Gaya hidup sosial, Pendidikan bahkan kegiatan masyarakat telah berubah oleh penggunaan internet [2]. Kejahatan merupakan salah satu dampak buruk penggunaan teknologi. Cybercrime merupakan stilah yang dikenal dengan penyalahgunaan penggunaan nternet dan media sosial.

Pertumbuhan teknologi yang semakin pesat diiringi oleh pertumbuhan sosial media dan aplikasi pesan nstan sudah melancarkan dalam tindak kejahatan siber dan aktivitas dampak negatif yang sangat serius [3]. Facebook messenger merupakan aplikasi pesan instan yang sangat mudah digunakan dan juga sangat mudah dalam membuat akun terutama dalam menyebarluaskan pornografi, pencemaran nama baik dan penipuan [4].

Penelitian terdahulu melakukan pencarian bukti digital Facebook Messenger menggunakan kerangka kerja NIST. Pada Penelitian tersebut melakukan skenario menggunakan handphone android Galaxy V+ SMG31HZ, melaksanakan metode rooting, memasang Facebook Messenger, pembuatan pesan, lalu melaksanakan nvestigasi menggunakan alat perangkat lunak forensik yang bernama Oxigen Forensics, setelah melaksanakan analisis terhadap ketiga alat perangkat lunak forensik tersebut. Hasil dari melaksanakan analisis dilaporkan sebagai barang bukti. Kerangka kerja NIST digunakan dalam melaksanakan analisis untuk bukti digital atau langkah dalam memperoleh informasi dari barang bukti. Menurut penelitian sebelumnya yang berjudul dentification of Digital Evidence on Android's Blackberry Messenger Using NIST Mobile Forensics Method [5], ditemukan beberapa hal 
yang bisa disimpulkan diantaranya NIST Mobile Forensics dapat digunakan dalam penemuan barang bukti. Barang bukti digital yang diantaranya adalah akun, text, gambar, dan audio, sedangkan hasil yang tidak didapatkan adalah video.

Pada penelitian kali ini melakukan investigasi digital dengan melakukan perbandingan dua alat forensik berupa Magnet Axiom dan Belkasoft Ecidence Center untuk memperoleh barang bukti yang ditemukan dari aplikasi pesan nstan Facebook Messenger. Penelitian melaksanakan kerangka kerja National nstitute of Justice (NIJ). Simulasi forensik dilakukan terhadap kasus penyebaran pornografi menggunakan aplikasi Facebook Messenger sebagai media komunikasi pada smartphone berbasis Android. Pelaku kejahatan melakukan penghapusan data dalam aplikasi untuk menghilangkan jejak. Barang bukti yang dicari adalah gambar, video, akun, percakapan, email, waktu kejadian, dan pesan suara.

\section{METODE PENELITIAN}

Penelitian ini menggunakan kerangka kerja digital forensik National nstitute of justice (NIJ) untuk mendapatkan bukti digital dan mencatat informasi yang didapatkan untuk akhirnya dikumpulkan melaksanakan mekanisme data terpusat [6]. Investigasi forensik dimaksudkan untuk mendapatkan barang bukti menggunakan alat forensik yang berbeda beda supaya mendapatkan proses yang detail [7]. Mempertahankan barang bukti dan mengetahui pelaku siber sehingga digunakan untuk bukti di pengadilan merupakan tujuan digital forensik. nvestigasi forensik dalam kerangka kerja NIJ memiliki sejumlah tahap untuk dapat melakukan yaitu seperti pada Gambar 1.

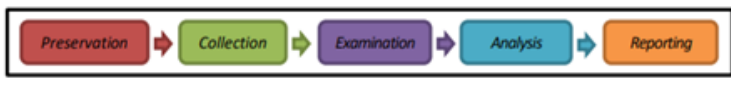

Gambar. 1 Tahapan dalam metode NIJ

Tahapan dalam NIJ seperti pada Gambar 1 diuraikan seperti berikut.

1) Preservation, yaitu melakukan upaya mempertahankan keaslian dan pengaman bukti yang sudah ditemukan untuk tidak berubah dan hilang.

2) Collection, yaitu melakukan kegiatan pengumpulan data untuk membantu segala proses kegiatan penyidikan untuk mencari barang bukti.

3) Examination, yaitu melakukan nvestigasi data yang didapatkan dengan proses forensik, otomatis atau tidak otomatis dan menentukan bahwa yang diperoleh adalah file otentik atau asli.

4) Analysis, yaitu ekstraksi dokumen yang bermaksud tujuan untuk memastikan bukti signifikan dan bernilai dalam pembuktian.

5) Reporting, yaitu melakukan pembuatan laporan dari barang bukti digital yang didapat melalui proses pemeriksaan dan analisis.

\section{A. Skenario Kasus}

Penelitian dilakukan dengan simulasi kasus kejahatan pornografi. Proses simulasi diperlukan untuk membantu dalam menentukan kronologis proses terjadinya kasus terindikasi tindak pidana penyebaran pornografi, sedangkan skenario seperti pada Gambar 2.

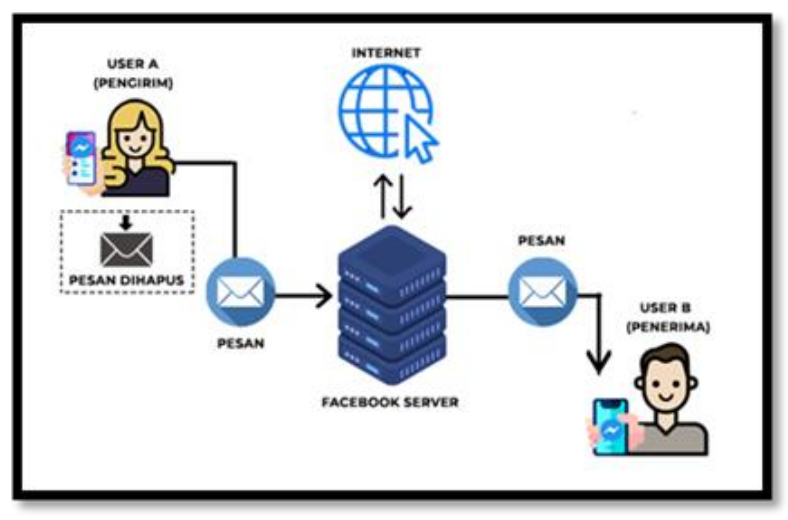

Gambar 2. Kronologi aktivitas komunikasi Facebook Messenger

Berdasarkan simulasi kasus, ada dua pengguna yang menggunakan Facebook Messenger untuk berkomunikasi yaitu user a (Pengirim Pesan, Pelaku Kejahatan) dan user b (Penerima Pesan, Korban Kejahatan). User a memiliki smartphone Samsung Galaxy Star GT-S5282, sedangkan user b memiliki smartphone Samsung J4 Prime. Keduanya memiliki akun media sosial Facebook Messenger. Akun digunakan untuk berkomunikasi satu sama lain yaitu mengirim obrolan dan foto melalui fitur Facebook Messenger. User a mengirim obrolan dan gambar yang menunjukkan gambar Wanita menggunakan pakaian terbuka kepada user b. Setelah mengirim obrolan dan gambar, user a segera menghapus semuanya untuk menghilangkan bukti. User b sebagai korban melapor ke pihak berwenang untuk kejadian yang dialami.

Pihak berwenang menanggapi laporan user $\mathrm{b}$ dengan mengeluarkan surat penggeledahan kepada user a untuk mengamankan smartphone yang digunakan untuk mengakses Facebook Messenger untuk berkomunikasi user b. Smartphone ni dijadikan barang bukti elektronik. Untuk prosedur selanjutnya, pemeriksaan smartphone milik user a dilakukan nvestigasi. Verifikasi pengembalian barang bukti digital dilakukan terhadap smartphone milik user $\mathrm{b}$ (korban) untuk memastikan bahwa bukti pada smartphone milik user a (pelaku) ada dan sama seperti yang diterima user b.

Setelah itu kasus yang menunjukkan kejahatan penyebaran pornografi dapat berlanjut di pengadilan. Berdasarkan simulasi kronologis kasus yang terindikasi kejahatan pornografi tersebut maka tahapan berikut dapat diterapkan pada metode NIJ.

Investigasi barang bukti difokuskan pada variabel nvestigasi barang bukti beserta jumlahnya sesuai yang dilihat pada Tabel 1 . 
TABEL I

VARIABEL DATA YANG DITELITI

\begin{tabular}{|c|l|c|}
\hline No & Variabel & Jumlah \\
\hline 1 & Versi Aplikasi & 1 \\
\hline 2 & Akun & 1 \\
\hline 3 & Email & 1 \\
\hline 4 & Percakapan & 1 \\
\hline 5 & Waktu Kejadian & 1 \\
\hline 6 & Gambar & 2 \\
\hline 7 & Video & 1 \\
\hline 8 & Audio & 1 \\
\hline 9 & Url & 1 \\
\hline 10 & IP Address & 1 \\
\hline 11 & Location & 1 \\
\hline
\end{tabular}

Dengan tabel variabel kemudian dilaksanakan nvestigasi forensik untuk memperoleh bukti digital yang diinginkan.

\section{B. Digital Forensics}

Digital forensics merupakan bidang disiplin teknologi dan pengetahuan yang memiliki manfaat pembenaran hukum pada tindakan kriminal berteknologi negatif atau cybercrime menurut lmiah hingga mendapatkan bukti digital supaya memenangkan pengadilan dalam memiliki bukti digital yang kuat [8].

Digital forensics merupakan bidang disiplin untuk mendapatkan bukti digital dalam suatu perbuatan kejahatan yang telah terjadi. lmu digital forensics telah digunakan untuk mendalami bermacam hal terutama dalam penyelesaian kasus kejahatan yang menggunakan nternet atau biasa disebut dengan cybercrime [9].

\section{Facebook Messenger}

Facebook menjadi pilihan media yang potensial untuk komunikasi dikarenakan pengguna media social di Indonesia yang jumlahnya cukup tinggi [10]. Facebook merilis aplikasi pesan nstan untuk mobile agar sejajar atau bersaing dengan layanan yang sama seperti Blackberry Messenger, Kakao talk, Whatsapp, dan Line. Pasar yang terus maju pesat untuk aplikasi pesan nstan membuat pendapatan tradisional operator selular menurun. Facebook Messenger merupakan aplikasi pesan nstan yang dapat mengirimkan teks, gambar, video, dan suara. Aplikasi ni ada untuk smartphone berbasis Android. OS, Blackberry, dan Windows. Aplikasi Facebook Messenger digunakan untuk mempermudah pengguna Facebook Messenger dalam pengiriman pesan antar sesama pengguna Facebook Messenger.

\section{Bukti Digital}

Bukti digital merupakan informasi yang disimpan atau dikirim berupa biner yang bisa dipertanggungjawabkan di pengadilan [11]. Bukti digital yang berhubungan dengan mobile seperti smartphone dapat ditemukan di call history, phonebook, SMS, MMS, photo, audio, video, dan lainnya. Pada umumnya, barang bukti digital terkait dengan penggunaan media social sebagai tempat untuk melakukan kejahatan sehingga bukti digital digunakan untuk membantu dalam mengadili kejahatan digital. Buktidigital rentan terjadi perubahan sehingga membuat keraguan terhadap keasliannya apabila tidak diatasi dengan tepat. Semua bentuk perubahan barang bukti dapat mengakibatkan kesimpulan yang salah dan bukti tidak dapat diterima [12]. Oleh karena itu penting untuk menjaga validitas bukti digital.

\section{E. Belkasoft Evidence Center}

Belkasoft Evience Center mampu memperoleh, mencari, menganalisis, dan menyimpan bermacam barang bukti yang ditemukan pada smartphone atau computer [13]. Alat forensik ni digunakan mampu mengeluarkan bukti digital dari bermacam sumber dan dapat menganalisis penyimpanan hard drive, Os BlackBerry, dan android backup setelah itu dengan otomatis menganalisis sumber data dan kemudian disimpan dalam suatu laporan [14].

\section{F. Magnet AXIOM}

Magnet AXIOM merupakan perangkat lunak forensik produksi Magnet Forensic yang dapat memproses dan menyiapkan bukti digital dari smartphone dan komputer menjadi suatu dokumen laporan [15]. Magnet AXIOM adalah alat pemeriksaan yang membantu profesional forensik dengan cepat menemukan data yang paling relevan dan memvisualisasikannya untuk analisis yang lebih baik. Magnet AXIOM banyak digunakan oleh profesional di bidang forensik digital untuk mencari bukti yang tidak dapat ditemukan oleh aplikasi forensik yang lain melakukan verifikasi data, dan mengintegrasikan gambar yang diperoleh alat lain kedalam suatu dokumen laporan untuk proses pemeriksaan [16]. Magnet AXIOM merupakan platform penyelidikan produksi Magnet Forensics, salah satu pemimpin global dalam pengembangan perangkat lunak forensik digital yang menerima, memeriksa, dan mengalokasikan informasi dari komputer, smartphone, dan tablet. Magnet AXIOM memungkinkan pakar forensik untuk memperoleh, mempelajari, dan menganalisis bukti digital dari komputer, smartphone, dan tablet [17].

\section{HASIL DAN PEMBAHASAN}

Tabel 2 merupakan informasi tentang alat yang dibutuhkan dalam penelitian ni. Proses untuk memperoleh bukti digital pada perangkat menggunakan alat perangkat lunak Magnet Axiom dan Belkasoft Evidance Center seperti pada Tabel 3 .

TABEL II

ALAT PENELITIAN

\begin{tabular}{|l|l|l|}
\hline No & Alat Penelitian & Deskripsi \\
\hline 1 & Smartphone & $\begin{array}{l}\text { Samsung J2 Prime G532G } \\
\text { Android 6.0.1 }\end{array}$ \\
\hline 2 & Laptop & $\begin{array}{l}\text { Asus A456U } \\
\text { Intel 5-6440 8.00 GB RAM }\end{array}$ \\
\hline 3 & USB Connector & $\begin{array}{l}\text { Media penghubung smartphone } \\
\text { dengan workstation }\end{array}$ \\
\hline 4 & $\begin{array}{l}\text { Facebook } \\
\text { Messenger }\end{array}$ & $\begin{array}{l}\text { Aplikasi Pesan instan } \\
\text { Versi 304.2.0.17.118 }\end{array}$ \\
\hline
\end{tabular}


TABEL III

ALAT FORENSIK

\begin{tabular}{|c|l|l|}
\hline No & Alat Forensik & \multicolumn{1}{c|}{ Deskripsi } \\
\hline 1 & Magnet Axiom & $\begin{array}{l}\text { Aplikasi yang digunakan dalam } \\
\text { menemukan barang bukti digital } \\
\text { pada smartphone yang berbasis } \\
\text { pada Windows }\end{array}$ \\
\hline 2 & $\begin{array}{l}\text { Belkasoft Evidence } \\
\text { Center }\end{array}$ & $\begin{array}{l}\text { Aplikasi yang digunakan dalam } \\
\text { menemukan barang bukti digital } \\
\text { pada smartphone yang berbasis } \\
\text { pada Windows }\end{array}$ \\
\hline
\end{tabular}

\section{A. Tahap Preservation}

Tahap preservation, merupakan tahap penjagaan keaslian dan pemeliharaan barang bukti [18]. Proses pemeliharaan barang bukti dilakukan supaya barang bukti tetap aman dan asli. Tahapan dilakukan dengan melangsungkan solasi kepada perangkat kepada nteraksi data keluar dan masuk. Teknik solasi dilaksanakan supaya menjauhkan hal yang tidak diinginkan yaitu bukti digital rusak dan merubah keaslian dokumen yang ada di perangkat tersebut [19]. Tahap preservation adalah dengan melakukan merubah kondisi perangkat kedalam mode pesawat seperti pada Gambar 3.

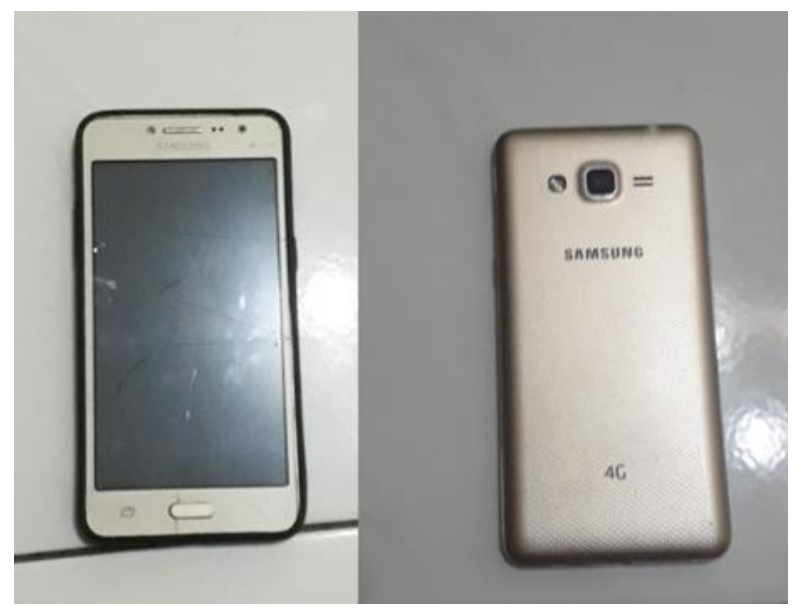

Gambar 3. Solasi barang bukti

Proses solasi sangat dibutuhkan dalam menurunkan terjadinya data pada perangkat berubah yang dapat dipengaruhi keaslian bukti digital..

\section{B. Tahap Collection}

Pada tahap collection, barang bukti pada smartphone mempunyai efek yang rawan karena apabila mengalami kerusakan, dokumen dan bukti digital yang ada dalam perangkat dapat lenyap atau corrupted, sehingga data tidak dapat terbaca [20]. Gambar 4. adalah proses pengumpulan data menggunakan Belkasoft Evidence Center.

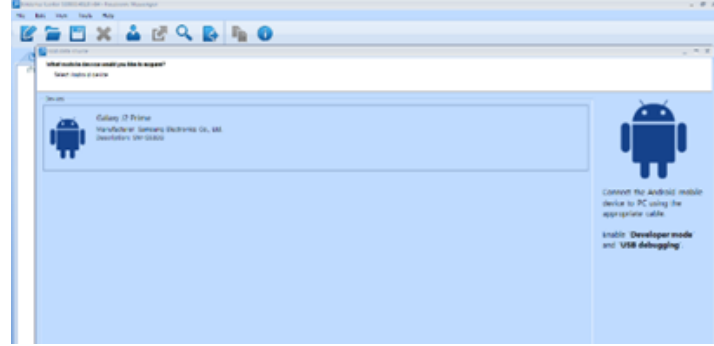

Gambar 4. Proses Collection Belkasoft Evidence Center

Belkasoft Evidence Center dapat melakukan backup system dan pengumpulan data pada perangkat smartphone lalu mengekstraksinya seperti pada Gambar 5.

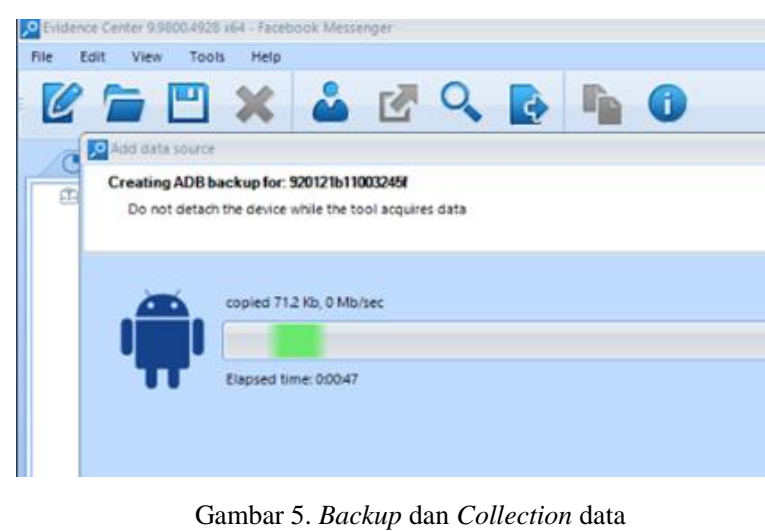

Hasil dari proses backup yang didapatkan dalam bentuk dokumen file yang bersumber dari dalam smartphone dengan ekstensi .img. Proses backup dan collection seperti pada Gambar 6.

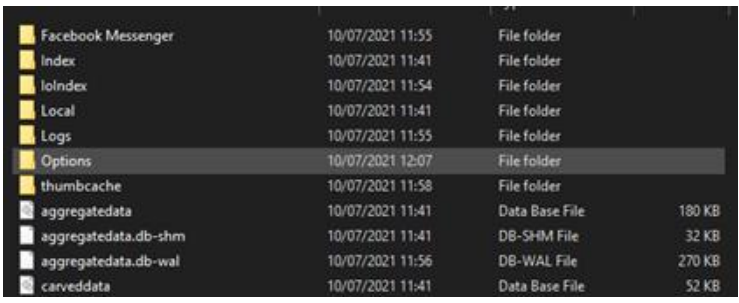

Gambar 6. Physical mage

Setelah dilaksanakan backup dan collection, tahapan berikutnya yaitu melaksanakan ekstraksi data dengan menggunakan Belkasoft Evidence Center seperti pada Gambar 7 dan proses ekstraksi Magnet Axiom seperti pada Gambar 8.

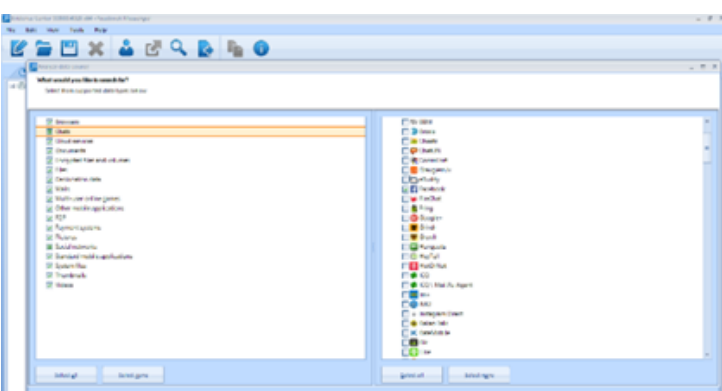

Gambar 7. Proses ekstraksi Belkasoft Evidence Center 


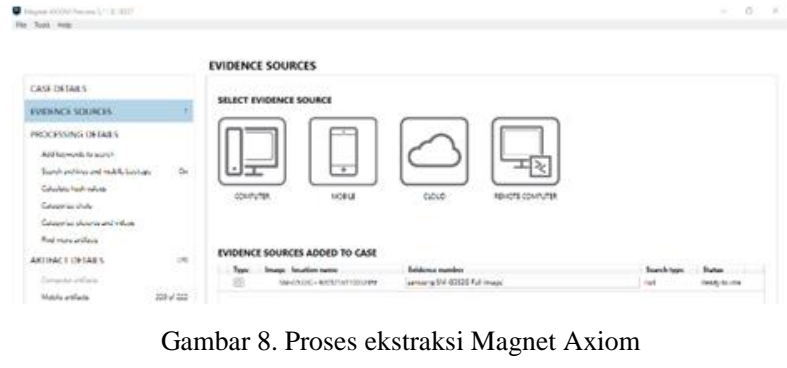

\section{Tahap Examination}

Hasil ekstraksi data menggunakan Magnet Axiom dan Belkasoft Evidance Center didapatkan data pada storage smartphone. Hasil ekstraksi yang telah dilaksanakan dalam bentuk file dengan format .belkaml untuk Belkasoft Evidence Center dan format .mfdb untuk Magnet Axiom. Data yang didapatkan dari smartphone Samsung J2 Prime seperti pada Gambar 9 dan Gambar 10.

\begin{tabular}{|c|c|c|c|}
\hline Facebook Messenger & 11/07/2021 6:07 & File folder & \\
\hline [ 920121b11003245f.ab & 10/07/2021 11:51 & AB File & $40.462 \mathrm{~KB}$ \\
\hline di.belkaml & $10 / 07 / 202111: 51$ & BELKAML File & $1 \mathrm{~KB}$ \\
\hline Screenshot_1 & 10/07/2021 11:45 & PNG File & $54 \mathrm{~KB}$ \\
\hline Ecreenshot_2 & 10/07/2021 11:46 & PNG File & $51 \mathrm{~KB}$ \\
\hline
\end{tabular}

Gambar 9. Hasil ekstraksi Belkasoft Evidence center

Proses ekstraksi menggunakan Magnet Axiom didapatkan data yang mencakup file dan direktori yang berada pada storage pada smartphone tersebut. Data yang didapatkan dari Smartphone Samsung J2 Prime dapat dilihat pada Gambar 10. Hasil dari ekstraksi didapatkan file dalam memori perangkat mobile, metode ni mendapatkan akses ke semua file yang didapatkan pada ekstraksi yang terdapat pada aplikasi pesan nstan Facebook Messenger.

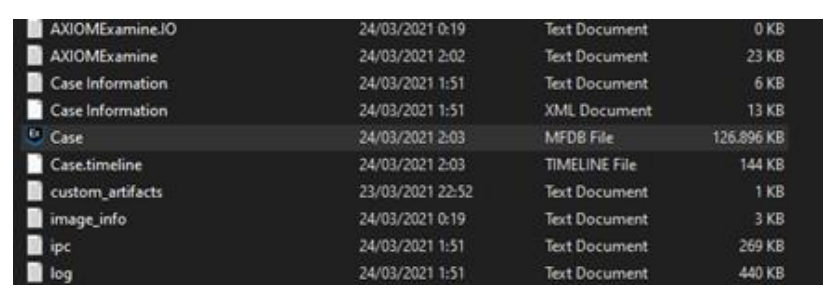

Gambar 10. Hasil ekstraksi Magnet Axiom

\section{Tahap Analysis}

Hasil dari analisis aplikasi Facebook Messenger yang didapat dari case.mfdb adalah informasi yang menunjukkan file artifacts berjumlah 34 dan file system berjumlah 12 sesuai dengan yang ada pada Gambar 11 .

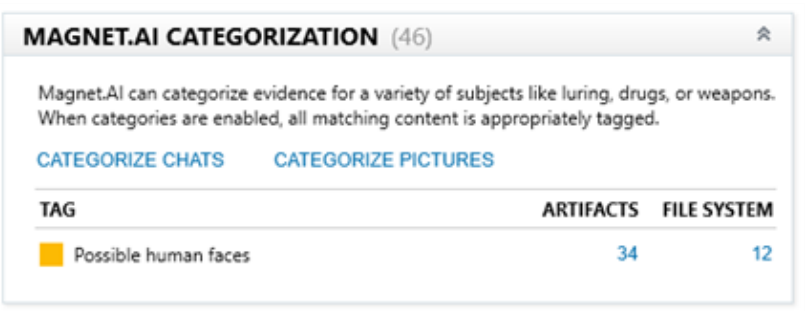

Gambar 11. Kategori Magnet Axiom

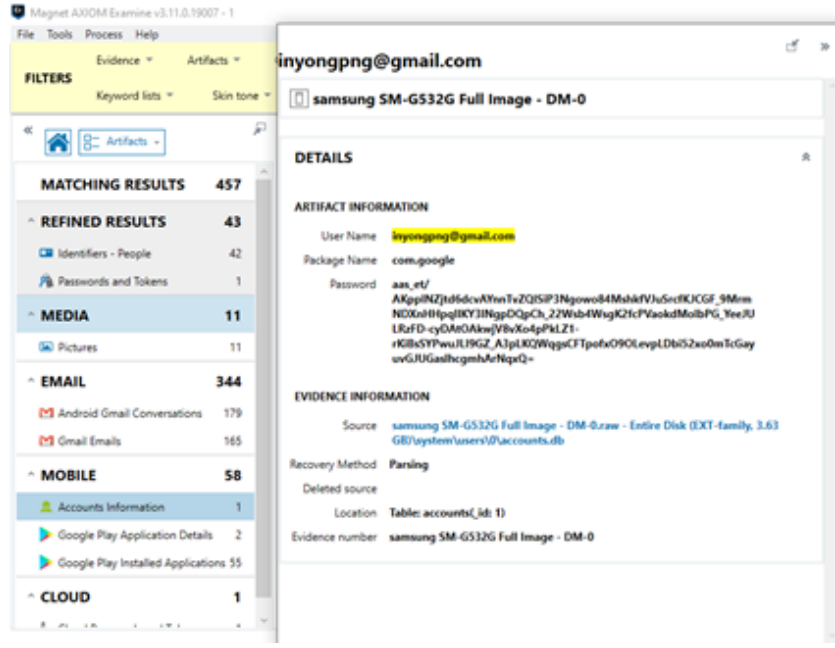

Gambar 12. Informasi Account Facebook Messenger

Selain email akun yang dipakai juga dapat diperoleh barang bukti foto yang dihapus dari Facebook Messenger seperti yang ditunjukkan pada Gambar 13 dan Gambar 14. Pada simulasi ni dilakukan dengan melakukan aktivitas percakapan oleh pelaku kejahatan dengan mengirimkan 2 gambar, 1 video, dan 2 audio kepada pelanggan. Data dalam aktivitas pengiriman kemudian dihapus untuk menghilangkan jejak.

Investigasi digital dilakukan untuk mendapatkan kembali data aktivitas kegiatan kejahatan yang telah dihapus. Bukti-bukti akan didapatkan dengan menggunakan Software Magnet Axiom dan Belkasoft Evidence Center. Terakhir dilakukan akurasi setiap tools yang digunakan untuk mengukur akurasi pada setiap tools yang digunakan dalam kemampuan mendapatkan bukti digital.

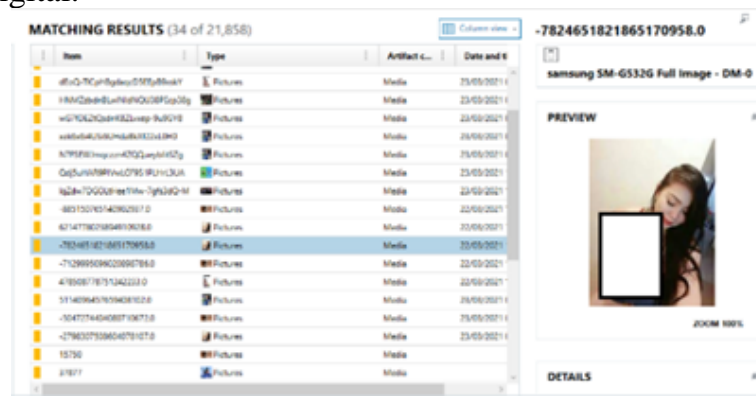

Gambar 13. Barang Bukti Foto (1)

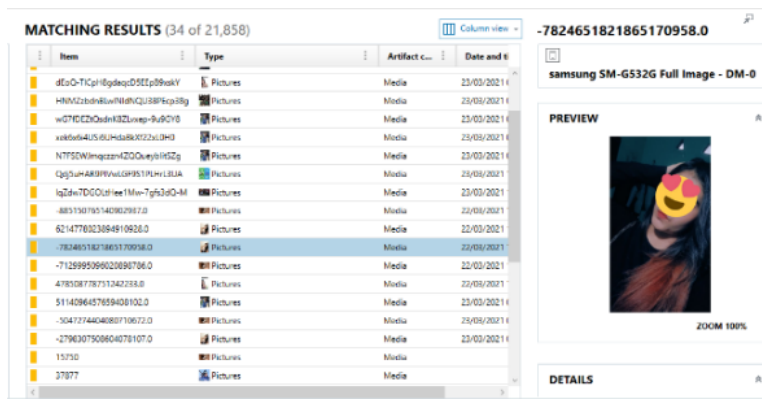

Gambar 14. Barang bukti Foto (2) 
Hasil dari analisis juga menemuka media berupa 1 video dari 1 video yang dikirimkan pada akun Facebook Messenger. Barang bukti video seperti yang ditunjukan pada Gambar 15.

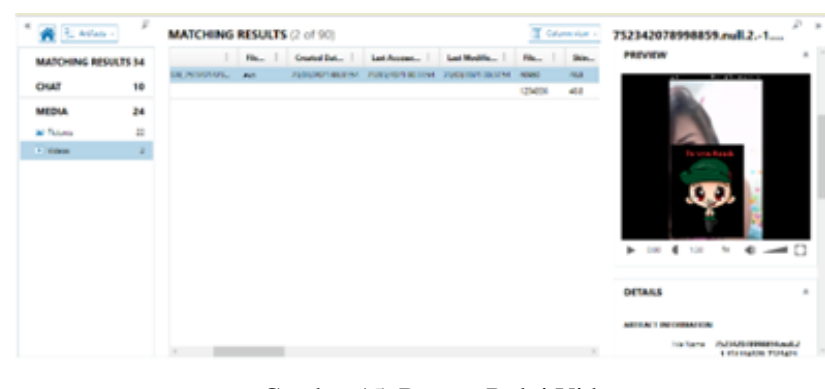

Gambar 15. Barang Bukti Video

\section{E. Tahap Reporting}

Setelah dianalisis terhadap barang bukti dapat disimpulkan bahwa dengan menerapkan forensik pada Android maka artefak digital yang berkaitan sebagai barang bukti berhasil didapatkan. Berdasarkan skenario dan simulasi yang dilakukan bahwa artefak digitak bukti penyebaran dan pengunggahan gambar dan video yang dilakukan oleh pelaku jasa pornografi berhasil didapatkan.

Setelah dilaksanakan analisis terhadap aplikasi Facebook Messenger menggunakan Magnet Axiom dan Belkasoft Evidence center ditemukan perbandingan terhadap fitur yang diberikan kedua aplikasi yang digunakan. Perbandingan dilaksanakan menggunakan hasil ekstraksi yang ditunjukan pada Tabel IV. Magnet Axiom memiliki akurasi sebesar 90,91\% dan Belkasoft Evidence Center sebesar $45,45 \%$.

TABEL IV

HASIL VARIABEL

\begin{tabular}{|c|c|c|c|c|}
\hline $\begin{array}{l}\mathbf{N} \\
\mathbf{o}\end{array}$ & $\begin{array}{c}\text { Informa } \\
\mathrm{si}\end{array}$ & $\begin{array}{c}\text { Juml } \\
\text { ah }\end{array}$ & Mgnet xiom & $\begin{array}{c}\text { Belkasoft } \\
\text { Evidence } \\
\text { Center }\end{array}$ \\
\hline 1 & $\begin{array}{c}\text { Versi } \\
\text { Aplikasi }\end{array}$ & 1 & 304.2 .0 .17 .118 & $\begin{array}{c}304.2 .0 .17 \\
118\end{array}$ \\
\hline 2 & Akun & 1 & 100062123935886 & $\begin{array}{c}\text { Tidak } \\
\text { Didapatkan }\end{array}$ \\
\hline 3 & Email & 1 & $\begin{array}{c}\text { inyongpng@gmail. } \\
\text { com }\end{array}$ & $\begin{array}{c}\text { Tidak } \\
\text { Didapatkan }\end{array}$ \\
\hline 4 & $\begin{array}{c}\text { Percakap } \\
\text { an }\end{array}$ & 1 & Tidak Didapatkan & Didapatkan \\
\hline 5 & $\begin{array}{c}\text { Waktu } \\
\text { Kejadian }\end{array}$ & 1 & Didapatkan & $\begin{array}{c}\text { Tidak } \\
\text { Didapatkan }\end{array}$ \\
\hline 6 & Gambar & 2 & $\begin{array}{c}\text { Didapatkan } 2 \\
\text { Gambar }\end{array}$ & $\begin{array}{c}\text { Didapatkan } \\
2 \text { Gambar }\end{array}$ \\
\hline 7 & Video & 1 & $\begin{array}{c}\text { Didapatkan } 1 \\
\text { Video }\end{array}$ & $\begin{array}{c}\text { Didapatkan } \\
1 \text { Video }\end{array}$ \\
\hline 8 & Audio & 1 & $\begin{array}{l}\text { Didapatkan } 1 \\
\text { Audio }\end{array}$ & $\begin{array}{c}\text { Tidak } \\
\text { Didapatkan }\end{array}$ \\
\hline 9 & URL & 1 & Didapatkan & Didapatkan \\
\hline 10 & $\begin{array}{c}\text { IP } \\
\text { Adress }\end{array}$ & 1 & Didapatkan & $\begin{array}{c}\text { Tidak } \\
\text { Didapatkan }\end{array}$ \\
\hline 11 & Location & 1 & Didapatkan & $\begin{array}{c}\text { Tidak } \\
\text { Didapatkan }\end{array}$ \\
\hline \multicolumn{3}{|c|}{ Keberhasilan (\%) } & 90,91 & 45,45 \\
\hline
\end{tabular}

\section{KESIMPULAN}

Dari uraian yang dijabarkan di atas dengan kerangka kerja NIJ menggunakan tools Magnet Axiom dan Belkasoft Evidence center mampu melakukan nvestigasi forensik tindak kejahatan penyebaran pornografi terhadap aplikasi nstant messenger pada Android yaitu Facebook Messenger. Hasil yang didapat dari penelitan dapat digunakan untuk bukti oleh nvestigator atau penyidik dalam menangani kasus kejahatan dan acuan penyidik dalam mencari barang bukti pada kasus-kasus penyebaran konten pornografi pada aplikasi Facebook Messenger. Magnet Axiom mendapatkan hampir semua barang bukti dengan tingkat keberhasilan 90,91\%, sedangkan Belkasoft Evidence center hanya mendapatkan $45,45 \%$. Penelitian lebih lanjut dapat dilakukan menggunakan tools forensik dan metode lain yang dimungkinkan untuk digunakan sehingga saling melengkapi dan mendapatkan hasil terbaik.

\section{REFERENSI}

[1] D. Darmawati, "Komunikasi Pemersatu Ummat Suatu Cara Pengentasan Konflik," Al-Ittizaan: Jurnal Bimbingan Konseling Islam, vol. 1, no. 1, hal. 12-18, 2019.

[2] W. Mukti, U. Masruroh, \& D. Khairani, "Analisa dan Perbandingan Bukti Forensik Aplikasi Media Sosial Facebook dan Twitter pada Smartphone Android," Jurnal Teknik informatika (JIT), vol. 10, no. 1, hal. 73-84, 2017.

[3] D. Setiawan, "Dampak Perkembangan Teknologi Informasi dan Komunikasi Terhadap Budaya," Jurnal SIMBOLIKA: Research and Learning in Communication Study, vol. 4, no. 1, hal. 62-72, 2018.

[4] D. Nieborg \& A. Helmond, "The political economy of Facebook's platformization in the mobile ecosystem: Facebook Messenger as a platform instance," Media, Culture \& Society, no. 41, vol. 2, hal. 196-218, 2019.

[5] A. Yudahana, I. Riadi, \& I. Anshori, "Analisis Bukti Digital Facebook Messenger Menggunakan Metode NIST," Journal Research and Development, vol. 3 no.1, hal. 13-21, 2019.

[6] S. Saad, R. Umar, \& A. Fadlil, "Analisis Forensik Aplikasi Dropbox pada Android Menggunakan Metode NIJ pada Kasus Penyembunyian Berkas," Jurnal Sains Komputer \& informatika (JSAKTI), vol. 4, no. 2, hal.293-299. 2020.

[7] A. Hadi, A, I. Riadi, \& Sunardi, Forensik Bukti Digital Pada Solid State Drive (SSD) NVMe Menggunakan Metode National nstitute Standart and Technology (NIST). Seminar Nasional Teknologi Fakultas Teknik Universitas Krisnadwipayana, Jakarta 17 Juli 2019

[8] M. N. Al-Azhar, Digital Forensic: Panduan Praktis investigasi Komputer. Jakarta, Indonesia: Salemba Infotek, 2012.

[9] G. Horsman, "ACPO Pronciple for Digital Evidence: Time for an update," Forensic Science International: Reports, vol. 2, hal. 1076, 2020.

[10] W. Yasya dan P. Muljono, "Pengaruh Penggunaan Media Sosial Facebook dan Dukungan Online Terhadap Perilaku," Jurnal Studi Komunikasi dan Media, hal 71-86, 2019.

[11] I. Riadi, R. Umar, \& I. Nasrulloh, "Analisis Forensik Bukti Digital Pada Frozen SolidState Drive Dengan Metode National nstitute of Standards and Technology (NIST)," Jurnal Insand Comtech, vol. 2, no. 2, hal. 33-40, 2017.

[12] T. Rochmadi, "Deteksi Bukti Digital Pada Adrive Cloud Storage Menggunakan Live Forensik," CyberSecurity dan Forensik Digital, vol. 2, no. 2, hal. 65-68, 2019.

[13] W. Pranoto, I. Riadi \& Y. Prayudi, "Live forensics method for acquisition on the SolidState Drive (SSD) NVMe TRIM function," Kinetik: Game Technology, Information System, Computer Network, Computing, Electronics, and Control, vol. 5, no. 2, hal. 129-137, 2020. 
[14] I. Riadi, Sunardi, \& Sahiruddin, "Analisis Forensik Recovery pada Smartphone Android Menggunakan Metode National nstitute of Justice (NIJ)," Jurnal Teknologi Informasi (JURTI), vol. 3, no.1, hal. 87-95, 2019.

[15] S. Ikhsani, \& B. Hidayanto, "Analisa Forensik WhatsApp dan Line Messenger pada Smartphone Andorid sebagai Rujukan dalam Menyediakan Barang Bukti yang kuat dan valid di ndonesia," Jurnal Teknik ITS. vol. 5, no. 2, hal. 728-736, 2016.

[16] I. Zuhriyanto, A. Yudhana, I. Riadi, “Analisis Perbandingan Tools Forensic pada Aplikasi Twitter Menggunakan Metode Forensics Research Workshop," Science and Technology ndex. Vol. 5, no. 3 hal. 829-836. 2019.

[17] R. Prasongko, A. Yudhana, \& A. Fadlil, "Analisa Forensik Aplikasi Kakaotalk Menggunakan Metode National nstitute Standard
Technology," Seminar Nasional informatika 2018, hal. 129-133, 2018.

[18] W. Mukti, U. Masruroh, \& D. Khairani, “Analisa dan Perbandingan Bukti Forensik Aplikasi Media Sosial Facebook dan Twitter pada Smartphone Android," Jurnal Teknik informatika (JIT), vol. 10, no. 1, hal. 73-84, 2017.

[19] I. Riadi, A. Yudhana, \& M. Putra, "Forensic Tool Comparison on Instagram Digiral Evidance on Android with The NIST Method,' Scientific Journal of informatics, vol. 5 no. 2, hal. 235-247. 2018.

[20] K. Mahendra, \& K, Mogi, "Digital Forensic Analysis of Michat Aplications on Android as Digital Proof in Handling Online Prostitution Cases," Jurnal Elektronik Imu Komputer Udayana. Vol, 9, no. 3, hal. 381-390, 2021. 